\title{
EVALUATION OF GEOTEXTILES APPLICATION IN SANDY SOIL: THEIR EFFECT ON WATER DEPLETION, HYDRAULIC CONDUCTIVITY AND INFILTRATION
}

\author{
W.M. Omran \\ Department of Soil Science, Faculty of Agriculture, Menoufia University, Egypt
}

Received: Sep. 24, 2018

Accepted: Mar. 20, 2019

\begin{abstract}
Geotextile is an expression used to denote the fabrics or textiles used in soils for different purposes. The special properties of the fabrics are the controller of their action and profession. The research aims to study the effect of applying natural and synthetic geotextiles on the subsurface layer of sandy soil. Hydraulic conductivity, water depletion and infiltration (cumulative and rate) were measured for untreated and treated soil samples. The results showed that, compost and the two types of geotextiles appeared an ameliorative effect on the aforementioned parameters, such as slowing down vertical water movement, allowing better horizontal wetting and increasing water maintenance in the soil comparing to control. Both types of geotextiles were better than organic manures (i.e. compost) in many aspects such as their cleanliness, easiness to be packed and transported. These materials normally have not dust, bad smell, herb seeds, nematode or infection with insects or fungi. Natural and synthetic geotextile showed comparative results. The study recommended using polyester geotextile as an amendment for sandy soils because it is effective and environmentally safe, like natural geotextile (cotton), besides that, it is cheaper and more durable compared to cotton.
\end{abstract}

Key words: Geotextile, water depletion, hydraulic conductivity, infiltration, sandy soil.

\section{INTRODUCTION}

Geotextile is an expression used to denote the fabrics or textiles used in soils for different purposes, such as road reinforcement, structural engineering for soil, cracking, water runoff, and lining the sides of rivers, tributaries and seas to protect them from erosion (Misnon et al., 2014). In the period of 1926-1930, natural cotton fabrics and cotton fabrics saturated with asphalt oil (bitumen) were used to support agricultural soil on a limited scale (Pattnaik et al., 2016). In 1945 , geological fabrics were used to repair some cracks and to resist the erosion of beaches (Yamanouchi, 1986). Also, Koemer (2016) described the very earliest time frame (1950s and 1960s) of polymeric geotextiles and its great improvement and enhancement of geotextile industry. Bhattacharyya et al. (2009), Abu-Farsakh et al. (2013) and Cole (2015) studied various applications of geotextiles in agricultural soils and civil engineering to overcome their problems. Basu et al. (2009), Muller and Saathoff (2015) and Horrocks and Anand (2016) divided textile materials into three main types: natural fibers (e.g. cotton, linen, jute, wool and silk), Synthetic fibers made from natural materials (e.g. viscose and casin) and synthetic fibers made from synthetic polymer compounds (e.g. polystyrene, polyamide, polyester polyethylene, polypropylene and acrylic). The special properties of the fabrics, such as: hydraulic properties (e.g. permeability) and physical characteristics (e.g. pore size) and how these properties are affected by the soil properties and groundwater, are very important to know before purchasing and using geotextile, wherever, it controls its functional role and performance in the soil. Sandy soils have many problems in their properties. The major problems of 
sandy soils are its very rapid hydraulic conductivity, infiltration and the fast depletion of water. This induce a quick loss of irrigation water below plant root zone though deep percolation and do not allow water to move laterally. In such case, daily or very short irrigation interval is mandatory, which is very difficult and costly and may lead to huge reduction in obtained yield of cultivated plants. Many studies recommended compost and other organic amendments to improve the hydro-physical properties of sandy soils (Wanas and Omran, 2006; Omran et al., 2013; Dhanapal et al., 2018). Geotextiles, especially synthetic ones, are common in roads formation, soil fixation against erosion and coating drainage tubes. Limited researches studied the effect of geotextile on soil hydro-physical properties. Geotextiles made from natural and synthetic materials could be used as an alternative amendment as compost. Geotextiles (chosen in this study) are superior compared to compost in many aspects, such as: they are clean, easy to pack and transport, saves labor, easy to use and environmentally safe.
The research aims to study the effect of geotextiles on the depletion of water, hydraulic conductivity and infiltration properties of sandy soil compared to compost.

\section{MATERIALS AND METHODS}

Samples of sandy soil were collected from Sadat city area, Menoufia governorate, Egypt. These samples were used to evaluate the effect of applying compost and geotextiles (natural and synthetic as cotton and polyester, respectively) on soil hydraulic conductivity and the depletion of available water, those were measured to predict irrigation intervals, expressed in days, through weighing soil samples twice a day up to reaching permanent wilting point, PWP. The performed procedures and analyses, of soil physical (particle size distribution, real density, bulk density, field capacity, FC and PWP) and chemical properties, were conducted according to Ryan et al. (2001). Tables (1) and (2) present the physical and chemical properties of the studied soil, respectively.

Table (1): Physical analysis of the studied soil

\begin{tabular}{|c|c|c|c|c|c|c|c|c|}
\hline \multicolumn{2}{|c|}{ Particle size distribution, \% } & \multirow{2}{*}{ Texture } & \multicolumn{2}{|c|}{$\begin{array}{c}\text { Density } \\
\left(\mathrm{g} / \mathrm{cm}^{3}\right)\end{array}$} & \multicolumn{2}{c|}{$\begin{array}{c}\text { Soil moisture constants } \\
(\% b y \text { volume })\end{array}$} \\
\cline { 6 - 9 } C. sand & F. sand & Silt & Clay & & Real & Bulk & FC & PWP \\
\hline 73.15 & 19.11 & 6.49 & 1.25 & Sandy & 2.70 & 1.71 & 5.5 & 2.1 \\
\hline
\end{tabular}

Table (2): Chemical analysis for the studied soil

\begin{tabular}{|c|c|c|c|c|c|c|c|c|c|c|}
\hline \multirow{2}{*}{$\begin{array}{c}\text { Organic } \\
\text { matter } \\
(\%)\end{array}$} & \multirow{2}{*}{$\begin{array}{c}\mathrm{ES} / \mathrm{m} \\
\mathrm{dS}\end{array}$} & \multirow{6}{*}{$\begin{array}{c}\mathrm{pH} \\
(1: 1)\end{array}$} & \multicolumn{6}{|c|}{ Soluble ions, meq/100 g soil } \\
\cline { 4 - 11 } & & \multicolumn{5}{|c|}{ Cations } & \multicolumn{5}{c|}{ Anions } \\
\cline { 4 - 10 } & $\mathrm{Ca}^{2+}$ & $\mathrm{Mg}^{2+}$ & $\mathrm{Na}^{+}$ & $\mathrm{K}^{+}$ & $\mathrm{CO}_{3}{ }^{2-}$ & $\mathrm{HCO}_{3}^{-}$ & $\mathrm{Cl}^{-}$ & $\mathrm{SO}_{4}{ }^{2-}$ \\
\hline 0.00 & 0.62 & 7.48 & 2.11 & 1.21 & 2.39 & 0.00 & 0.00 & 2.24 & 2.67 & 0.80 \\
\hline
\end{tabular}


Samples of cotton and polyester geotextiles were collected from a garment factory. Most of the factories are located in the industry area of 6-October City in Egypt. The factories of garments used to pack the pails of the non-usable textile wastes of cotton and polyester in plastic bags to be sold. The average prices are about 4000 and 500 Egyptian pounds per ton, for cotton and polyester, respectively. The pails of cotton were non-uniform small pieces (i.e. different shapes and sizes) made from two kinds of $100 \%$ cotton fabrics. The pails of polyester were small pieces with different shape and size made from two kinds of $100 \%$ polyester fabrics. The average price of the packed plant based compost (in plastic bags) is about 450 Egyptian pounds per ton. The transportation cost should be equal and depend on the distance and the ordered amount. Maximum water holing capacity (MWHC) of compost, cotton geotextile and polyester geotextile was measured using 8 grams of compost, cotton or polyester textiles. Each one was placed in filter paper on a funnel. $100 \mathrm{~cm}^{3}$ was added to each sample. The drained water was received in graduated cylinders. The procedure was repeated several times to ensure saturation of the sample. After water stop draining, water content was calculated. Furthermore, the residual water content was determined using oven at $70{ }^{\circ} \mathrm{C}$. The total water content was estimated (MWHC). The thickness of the textiles was measured according to ASTM D 1777 -96 (2007) and the bulk density was determined. Average values of two kind's mixtures of textile wastes were considered, for the $100 \%$ cotton (Single Jersey and Single Pique) and $100 \%$ polyester (Mesh Pique and Interlock). The characteristics of geotextiles and compost are presented in Tables (3) and (4), respectively.

Table (3): Geotextiles characteristics

\begin{tabular}{|c|c|c|c|c|}
\hline Geotextile & \multicolumn{2}{|c|}{$100 \%$ Cotton } & \multicolumn{2}{c|}{$100 \%$ Polyester } \\
\hline Fabric Name & Single Jersey & Single Pique & Mesh Pique & Interlock \\
\hline Fabric Type & Knitte & Knitte & Knitte & Knitte \\
\hline Weight/area, g/m ${ }^{2}$ & 180 & 200 & 150 & 135 \\
\hline Thickness, mm & 0.34 & 0.35 & 0.25 & 0.19 \\
\hline Bulk density, g/cm & 0.53 & 0.57 & 0.60 & 0.71 \\
\hline hygroscopic water, \% & 6.8 & 7.1 & 0.8 & 0.5 \\
\hline MWHC, \% & 285.6 & 298.2 & 250.5 & 219.7 \\
\hline
\end{tabular}

Table (4): Compost characteristics

\begin{tabular}{|c|c|c|c|c|c|c|c|c|c|c|}
\hline $\begin{array}{c}\text { Organic } \\
\text { matter } \\
(\%)\end{array}$ & $\begin{array}{c}\text { Moisture } \\
\text { content } \\
(\%)\end{array}$ & $\begin{array}{c}\text { Bulk } \\
\text { density } \\
\mathrm{g} / \mathrm{cm}^{3}\end{array}$ & $\begin{array}{c}\mathrm{PH} \\
(1.2 .5)\end{array}$ & $\begin{array}{c}\mathrm{EC} \\
\mathrm{dS} / \mathrm{m} \\
(1: 1)\end{array}$ & $\begin{array}{c}\mathrm{C} / \mathrm{N} \\
\text { ratio }\end{array}$ & $\mathrm{N}(\%)$ & $\mathrm{P}(\%)$ & $\mathrm{K}(\%)$ & Ash (\%) & $\begin{array}{c}\text { MWHC } \\
(\%)\end{array}$ \\
\hline 38.1 & 19.3 & 0.77 & 7.17 & 2.9 & 18.7 & 1.11 & 0.73 & 0.95 & 59.2 & 321.1 \\
\hline
\end{tabular}


The experimental treatments were as follows:

1- Three soil amendments (i.e. compost and cotton and polyester geotextiles).

2- Two application rates of each amendment (i.e. 2 and 4 ton per feddan (Fed.), $4200 \mathrm{~m}^{2}$ ), in addition to control (without treatment).

3- Each treatment was conducted with three replicates.

Four inches in diameter PVC pipe $(10.16 \mathrm{~cm})$ was cut off to parts with length of $35 \mathrm{~cm}$. The bottom of each cylinder was closed with filter paper and piece of cloth. The cylinders were filled with 2774 grams of sandy soil, which should fill the cylinder to $20 \mathrm{~cm}$ height based on cylinder cross section area and soil bulk density. The mass of the soil, in each cylinder, was divided into two halves, except control treatment. The first half was added to the cylinders and the amendments (i.e. compost, cotton geotextile and polyester geotextile) with their appropriate applied rates to form a layer at $\mathbf{1 0} \mathrm{cm}$ under soil surface and the other half was added above the amendment layer. Each cylinder, employed to simulate the open field scale to depth of $20 \mathrm{~cm}$, was received 7.72 and 15.44 gram amendment for 2 and 4 ton/Fed., respectively. Thus, represent layers thickness of $1.24 \mathrm{~mm}, 1.73 \mathrm{~mm}$ and $1.46 \mathrm{~mm}$ for 2 ton per Fed., of compost, cotton geotextile and polyester geotextile, respectively. While similar values of 4 ton were $2.48 \mathrm{~mm}, 3.46 \mathrm{~mm}$ and $2.92 \mathrm{~mm}$, with an assumption that the amendments were applied to the cultivated part of the soil (half of the total area). The soil samples in the cylinders were saturated, from bottom to top by placing the cylinders above a sieve placed in basin. The water level in the basin was adjusted to be at about $5 \mathrm{~cm}$ of the cylinder bottom to allow water to move up slowly with capillary rise to ensure full saturation. After saturation the water was drained out of the basin (i.e. siphoned using hose) and the soil left exposed to open air to dry and weight twice a day to measure the depletion of soil water up to PWP. After the determination of the soil water depletion, soil samples, in the cylinders, were saturated again. A fixed water hydrostatic head of $12 \mathrm{~cm}$ was kept constant using upside-down filled plastic bottles with opened their down ends. A wooden frame was developed to hold the cylinders and bottles. The cylinders were placed directly above plastic funnel, supported by underneath shelf holder, of the same wooden frame, with holes fit the funnels. Jars and graduated cylinders were used to collect and measure water passed through the soil columns (i.e. saturated hydraulic conductivity of soil samples), as shown in Fig (1).

Soil infiltration (cumulative and rate) was measured in the open field, using double ring, according to Perrier and Salkini (1991). To apply amendments (Compost or geotextiles), the soil was drilled to $10 \mathrm{~cm}$ depth and soil particles were removed and a layer of each amendment was applied to cube area of $60 \mathrm{~cm}$ length with the desired application rate and the removed soil particles were returned back above the amendment layer. The double ring edges were buried up to $5 \mathrm{~cm}$ depth using a hummer at the specified areas.

The statistical analysis was performed using the SPSS, ver. 23, computer program. 


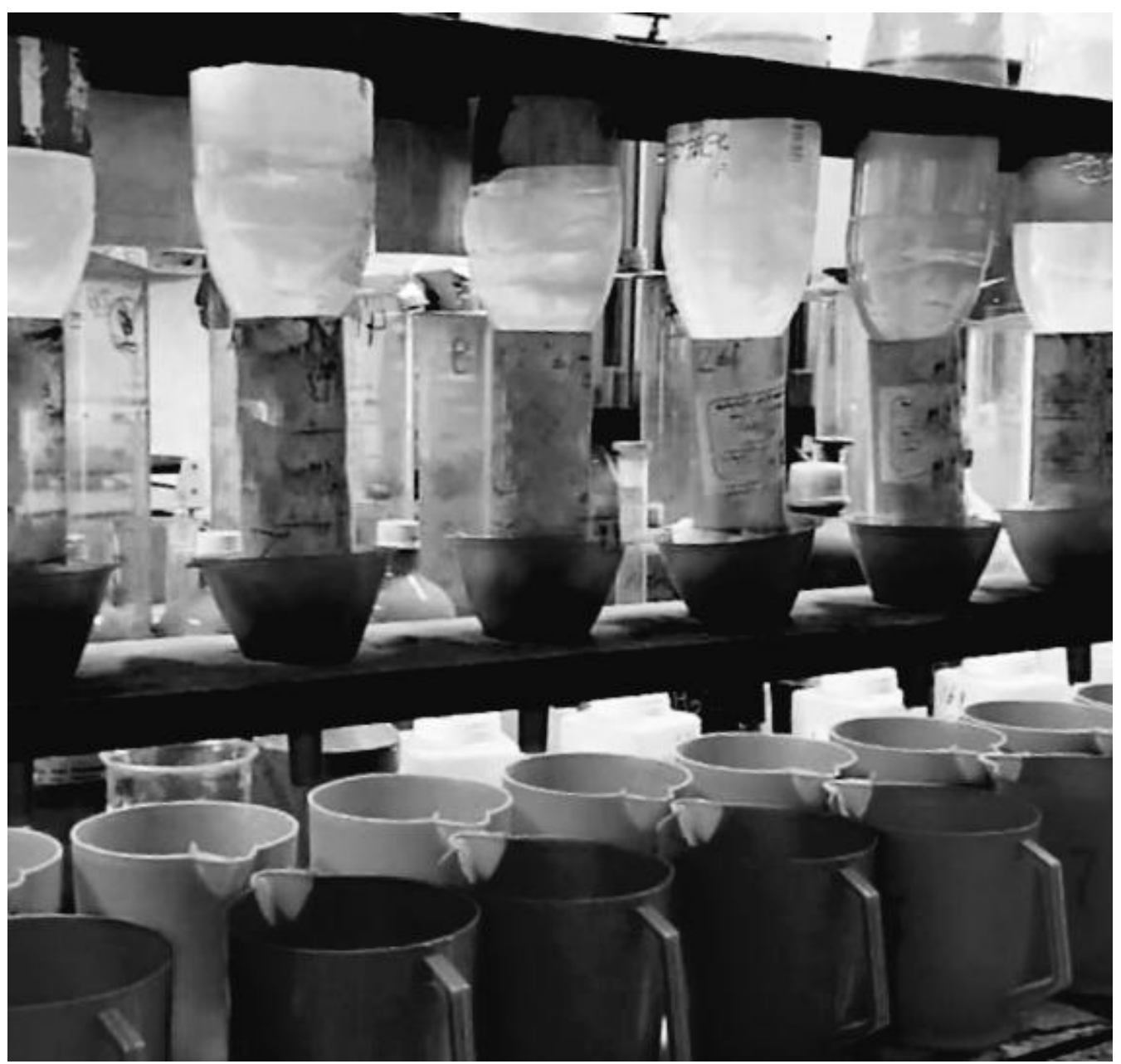

Fig (1): Hydraulic conductivity kit

\section{RESULTS AND DISCUSSION}

Two-way ANOVA was employed to test the effect of amendments (compost, cotton geotextile or polyester geotextile) with their application rates $(2$ or 4 ton/Fed.) on soil water depletion, saturated hydraulic conductivity and one dimensional water infiltration. Data in Table (5) show the average values and statistical results of these properties according to the different applied amendments and their application rates. The results (i.e. LSD values), presented in Table (5), reveal that, all treatments (compost, cotton geotextile and polyester geotextile) caused significant differences of all studied soil parameters comparing to control. In addition, significant differences were observed between the three amendments on water depletion, while, the significant differences was only between polyester geotextile and both of compost or cotton geotextile (no significant differences were found between cotton geotextile and compost) for their effect on hydraulic conductivity. Moreover, the results did not show significant difference between the three amendments each other. On the other hand, significant effect was found between 2 and 4 ton/Fed. application rates on water depletion and hydraulic conductivity. While, no significant difference was observed between the two application rates on cumulative and rate of infiltration. 
Table (5): Statistical analysis of different amendments and their application rates on studied soil parameters

\begin{tabular}{|c|c|c|c|c|c|c|c|c|}
\hline \multirow{3}{*}{$\begin{array}{l}\text { Treatments and } \\
\text { parameters }\end{array}$} & \multirow{3}{*}{ Control } & \multicolumn{4}{|c|}{ Amendment types } & \multicolumn{3}{|c|}{$\begin{array}{c}\text { Amendment } \\
\text { application rates }\end{array}$} \\
\hline & & \multirow{2}{*}{ Compost } & \multicolumn{2}{|c|}{ Geotextiles } & \multirow{2}{*}{ LSD } & \multirow{2}{*}{$\begin{array}{l}2 \text { ton } / \\
\text { Fed. }\end{array}$} & \multirow{2}{*}{$\begin{array}{l}4 \text { ton } / \\
\text { Fed. }\end{array}$} & \multirow{2}{*}{ LSD } \\
\hline & & & Cotton & Polyester & & & & \\
\hline Water Depletion & 2.2 & $5.0^{* *}$ & $4.6^{\star *}$ & $3.6^{* *}$ & 0.23 & $3.8^{* *}$ & $5.0^{* *}$ & 0.57 \\
\hline $\begin{array}{c}\text { Hydraulic } \\
\text { Conductivity, } \\
\text { cm/hour }\end{array}$ & 31.5 & $25.0^{\star *}$ & $24.6^{\star *}$ & $22.3^{\star *}$ & 0.92 & $26.3^{\star *}$ & $21.6^{\star *}$ & 1.7 \\
\hline $\begin{array}{c}\text { Cumulative } \\
\text { infiltration, } \mathrm{cm} \\
(90 \text { min average) }\end{array}$ & 47.7 & $24.2^{\star *}$ & $27.3^{\star *}$ & $26.5^{\star *}$ & \multirow{2}{*}{6.66} & $24.7^{\star *}$ & $27.3^{\star *}$ & \multirow{2}{*}{3.01} \\
\hline $\begin{array}{l}\text { Cumulative } \\
\text { infiltration, cm } \\
\text { (after } 90 \text { min) }\end{array}$ & 115.3 & $37.25^{\star *}$ & $41.45^{* *}$ & $39.88^{* *}$ & & $42.0^{\star *}$ & $37.1^{* *}$ & \\
\hline $\begin{array}{l}\text { Infiltration rate, } \\
\mathrm{cm} / \text { min ( } 90 \mathrm{~min} \\
\text { average) }\end{array}$ & 2.72 & $1.38^{\star *}$ & $1.50^{\star *}$ & $1.49^{\star *}$ & \multirow[t]{2}{*}{0.53} & $1.41^{\star *}$ & $1.50^{* *}$ & \multirow[t]{2}{*}{0.82} \\
\hline $\begin{array}{c}\text { Infiltration rate, } \\
\mathrm{cm} / \mathrm{min} \text { (after } 90 \mathrm{~min} \text { ) }\end{array}$ & 1.28 & $0.41^{\star *}$ & $0.46^{\star *}$ & $0.44^{\star *}$ & & $0.41^{* *}$ & $0.47^{\star *}$ & \\
\hline
\end{tabular}

${ }^{*}$ Significant at $5 \%$ level; ** Significant at $1 \%$ level

Fig (2) indicates that, compost and geotextiles (cotton and polyester) application caused a reduction in hydraulic conductivity compared to control. That is may be ascribed to the retarding effect of applied materials on water losses through deep percolation and advantage water to move laterally. Polyester geotextile had the lowest values with both application rates, followed by cotton geotextile and compost (no significant differences between them). In this respect, Hsieh (1995) discuss the capillary action in $100 \%$ cotton and polyester fabrics and concluded that, the fiber liquid surface attraction force causes the liquid to wet the fibers and is determined by fiber surface properties (i.e. pores size and distribution) which govern the water movement. Reducing hydraulic conductivity of sandy soil is great as it reduces the water losses, by deep percolation, and allows lateral water movement. Compost and geotextiles showed comparative results.

Fig (3) illustrates a retardant effect of compost, cotton geotextile and polyester geotextile on the depletion of available soil water. Accordingly, if we allow $\mathbf{5 0} \%$ depletion of soil maintained water, the irrigation interval should be 1.1 day for untreated soil. While the intervals should be 2.2, 2.8, 2, 2.6, 1.6 and 2.1 days for 2 ton compost, 4-ton compost, 2-ton cotton geotextile, 4-ton cotton geotextile, 2-ton polyester geotextile and 4-ton polyester geotextile, respectively. These are pronounced results, which may help in extending irrigation intervals. The advantages of such results in the field is that it may help in reducing water loss, labor and irrigation cost and makes the grown plant more flexible and tolerant to water deficit. This result was observed with all treatments compared to control. Compost and cotton geotextile showed comparative results and were better than 
polyester geotextile, in contrast with their effect on hydraulic conductivity. The applied amendments appeared a beneficial effect on physical properties, particularly water movement, wherever, the occurred reduction in hydraulic conductivity improved lateral water movement and minimized water loss through deep seepage.

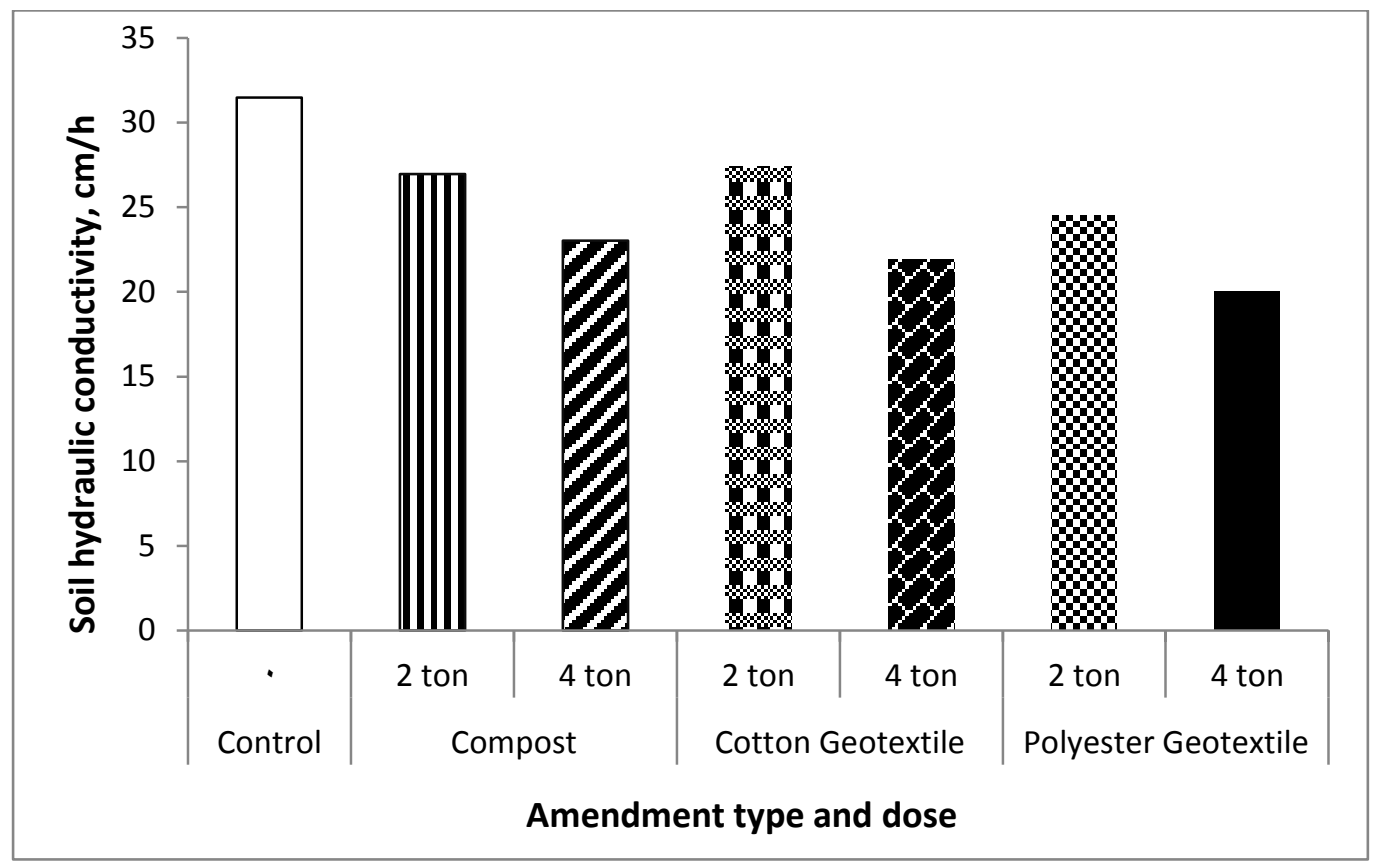

Fig (2): Effect of applied compost or geotextiles on soil hydraulic conductivity

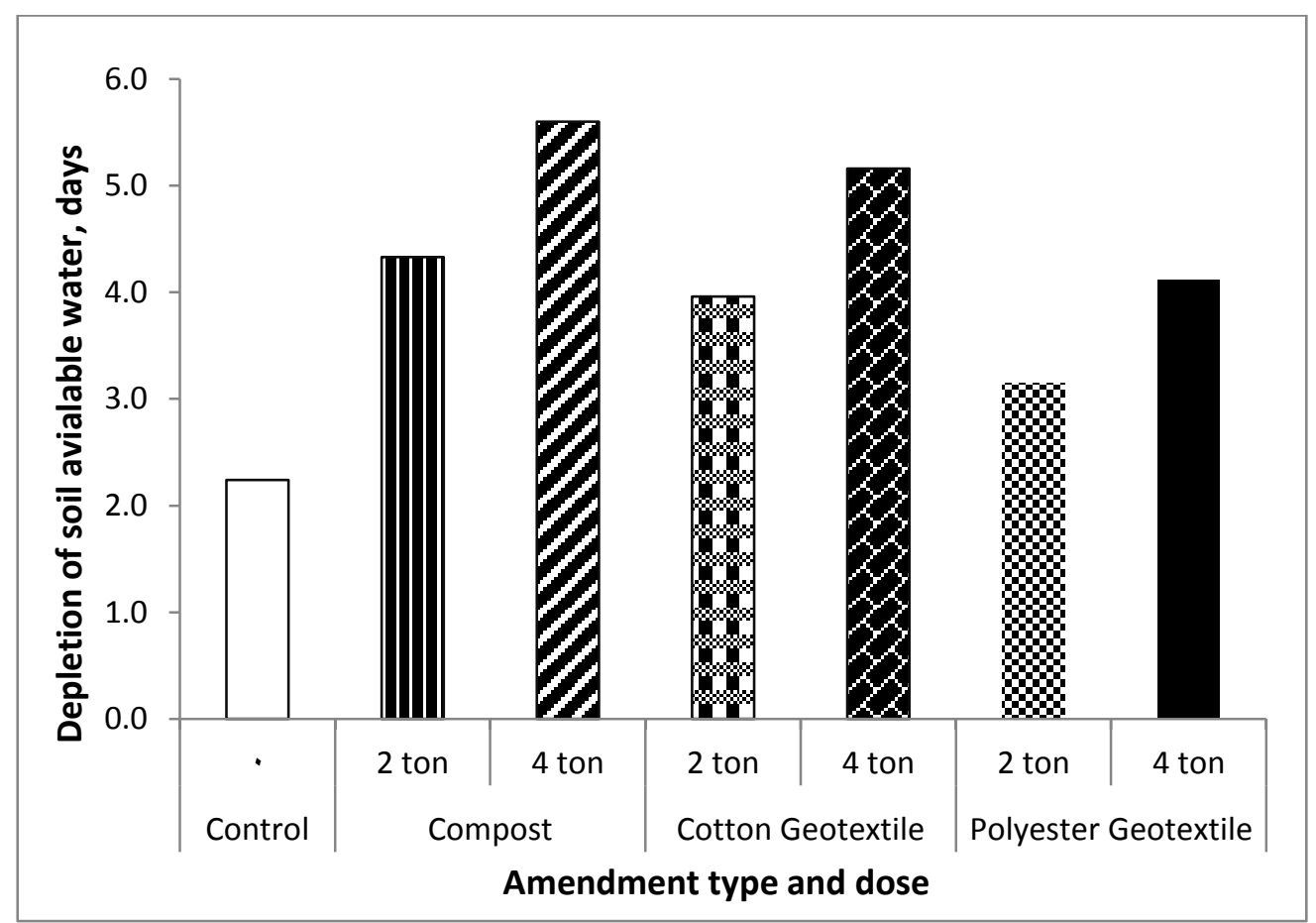

Fig (3). Effect of compost and geotextiles application on the depletion of soil retained water. 
Soil infiltration (rate and cumulative) was determined, wherever, it is more reliable in reflecting vertical water movement than hydraulic conductivity, to validate the results at the field scale. Figures (4, 5, 6, 7, 8 and 9) demonstrate the cumulative and rate of soil infiltration as affected by the application rates of compost, cotton geotextile and polyester geotextile, respectively. The figures clearly indicate a remarkable decrease of soil infiltration in open field with applying compost, cotton geotextile and polyester geotextile compared to the control. Comparative results were observed with the three amendments. The reduction of the vertical water movement that should increase the horizontal movement and improve the water status of sandy soils where water losses could be decreased, which guarantee better agriculture management. The regression equations and $R^{2}$ values were presented at each figure. Satisfied $R^{2}$ values declare the accuracy and the reliability of the obtained equations. The obtained regression equations could be employed in estimating the occurred changes in soil infiltration (cumulative and rate), regarding to the use of compost and geotextiles in sandy soil. In this respect, Iryo and Rowe (2004) and Bathurst et al. (2009) conducted experiments to test the infiltration in one-dimensional using sand columns. These studies manifested that, geotextiles delay infiltration and retarded seepage flow. On the other hand, Giménez-Morera et al. (2010) reported that, soil infiltration rate decreased and runoff increased due to the hydrophobic response of the cotton material. On the other hand, Nnadi et al. (2014) studied the effect of using a layer of geotextile to improve storm-water infiltration and reducing runoff and erosion.

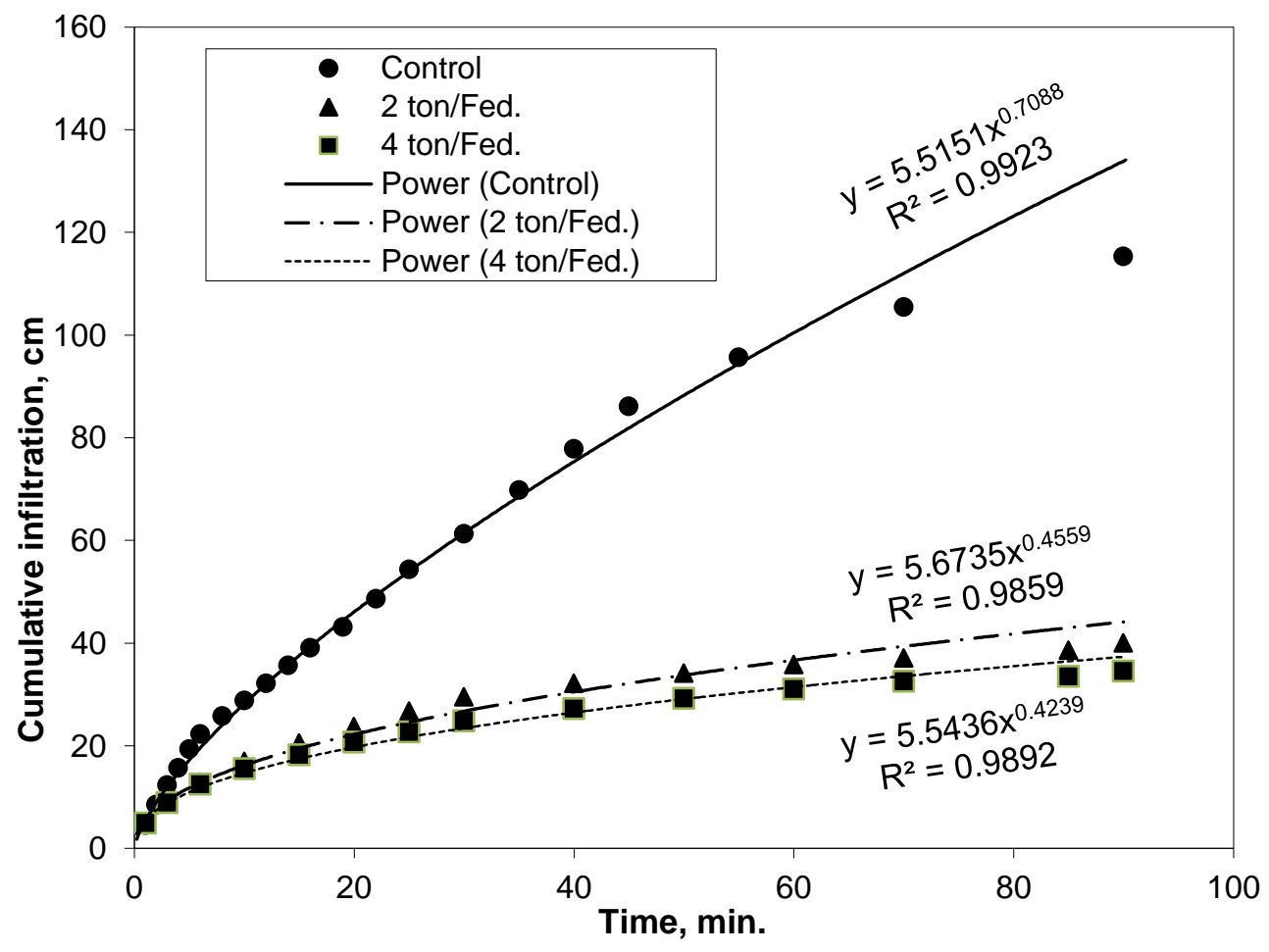

Fig 4: Effect of compost application on soil cumulative infiltration 


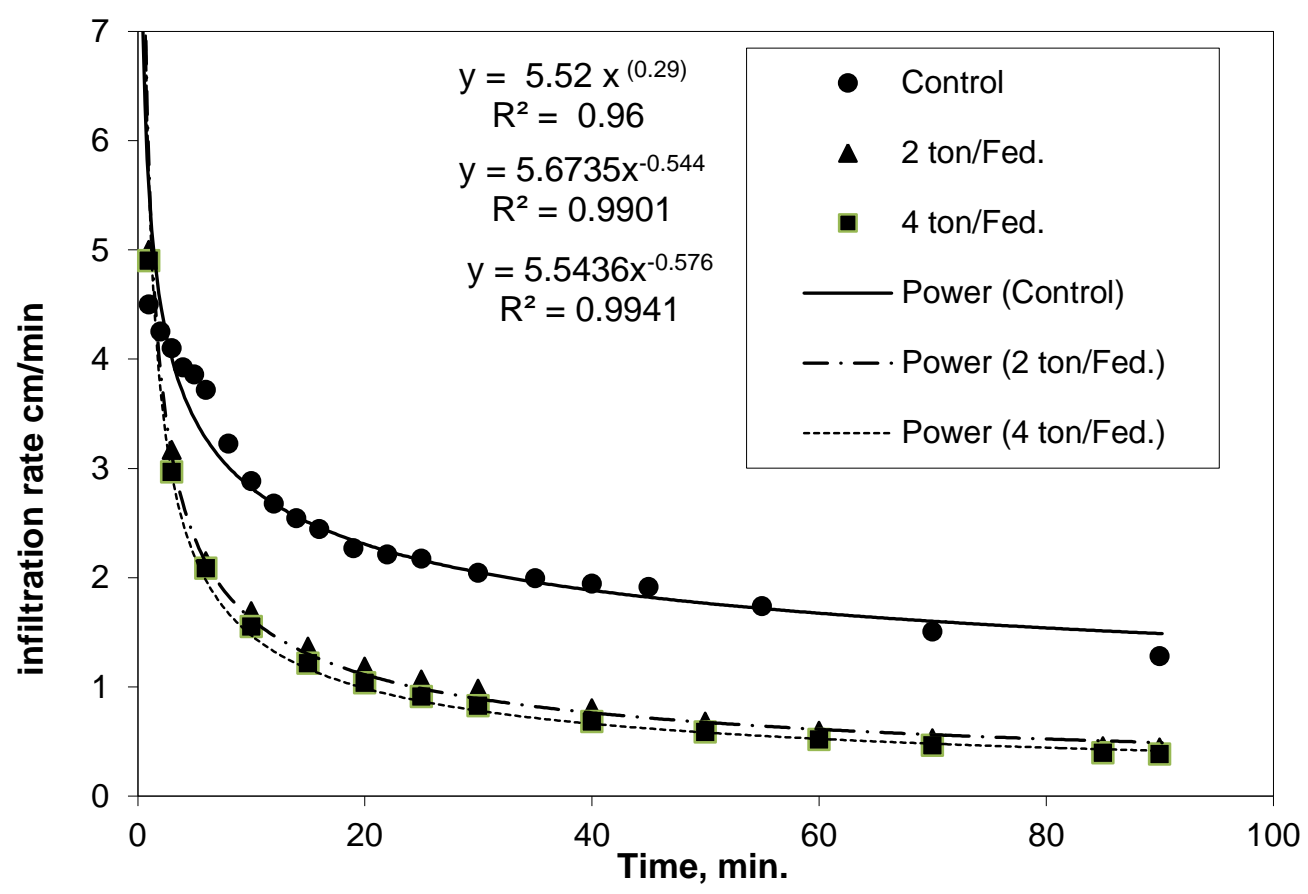

Fig 5: Effect of compost application on soil infiltration rate

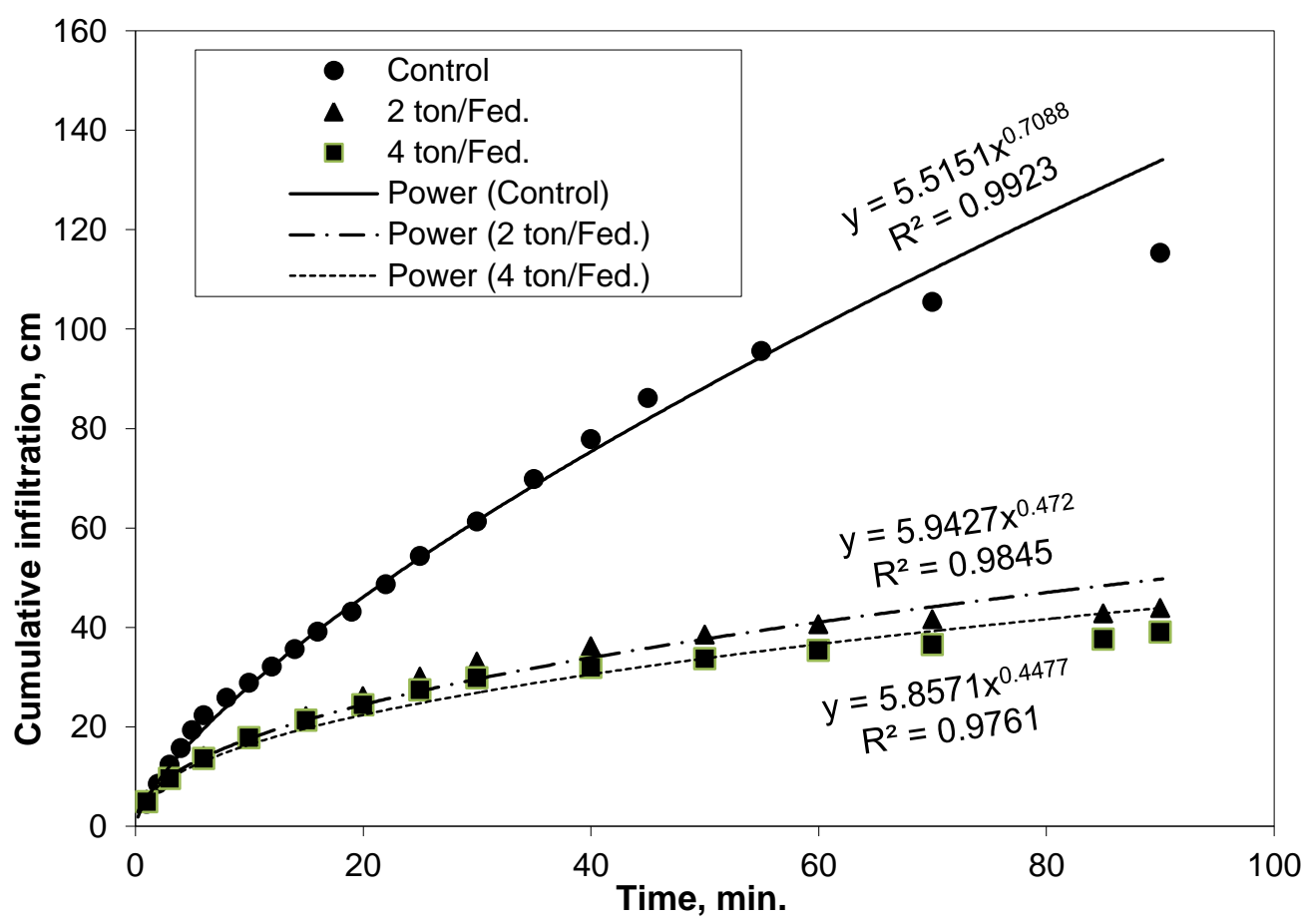

Fig 6: Effect of cotton geotextile on soil cumulative infiltration 


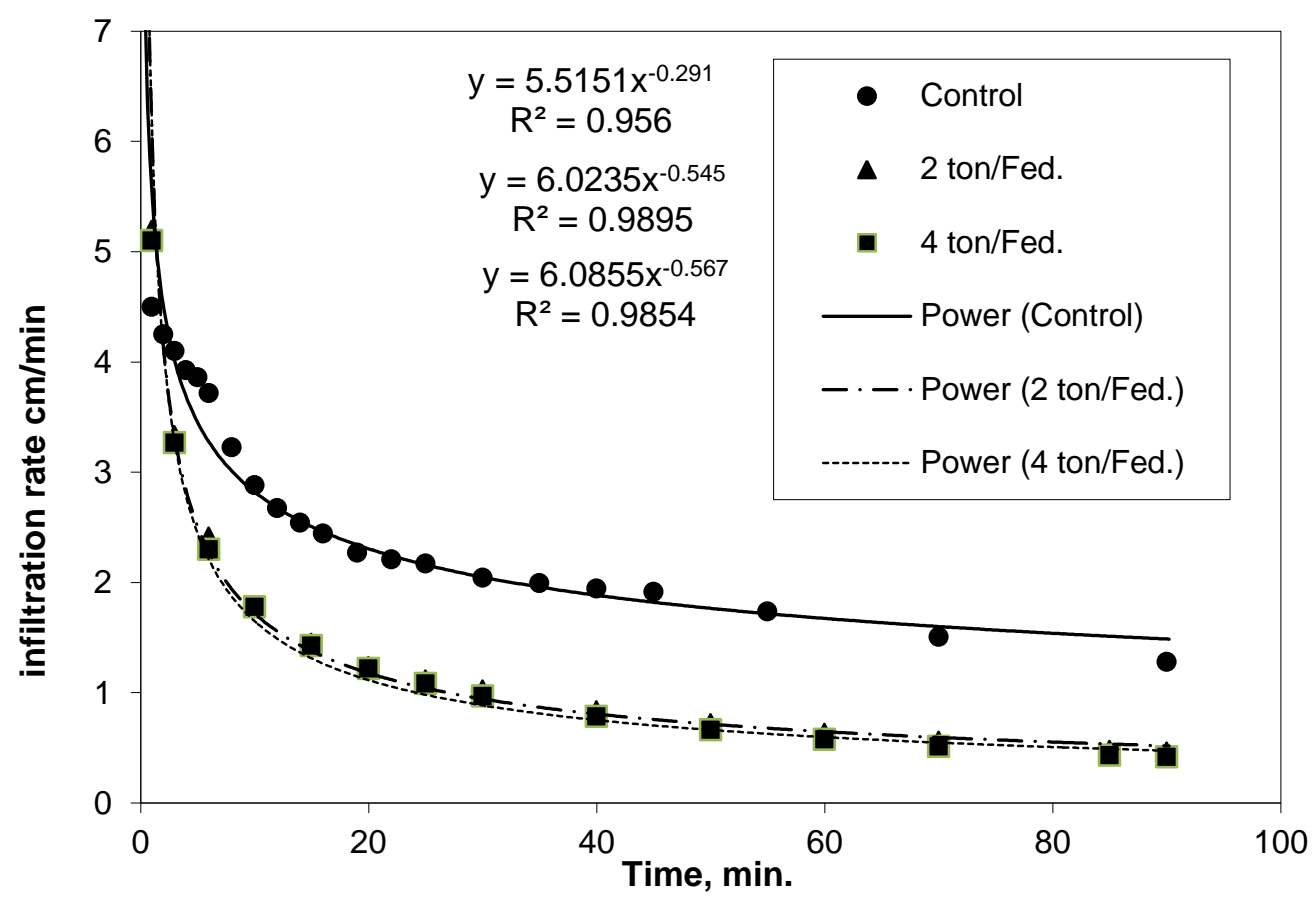

Fig 7: Effect of cotton geotextile application on soil infiltration rate

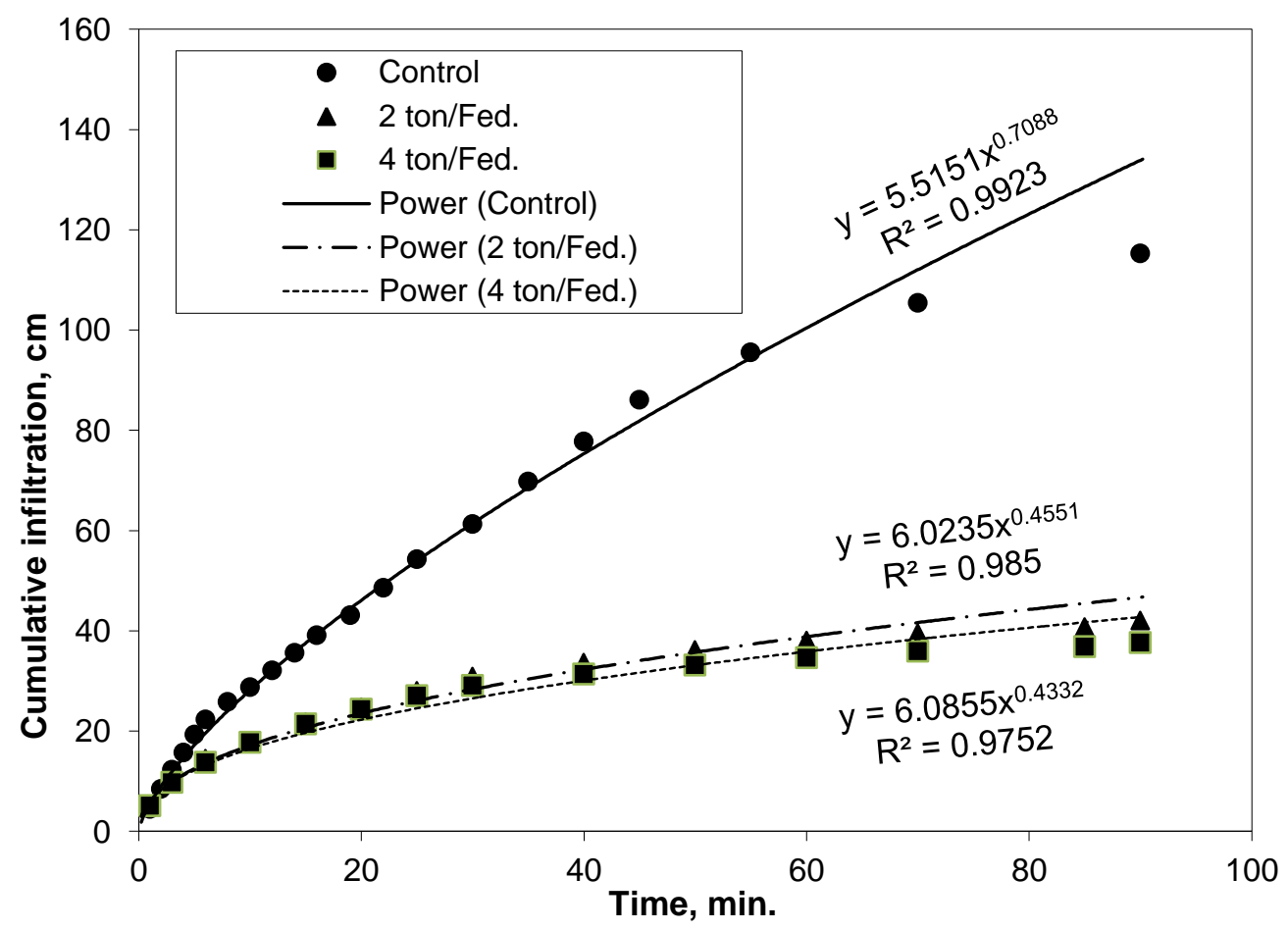

Fig 8: Effect of polyester geotextile on soil cumulative infiltration 


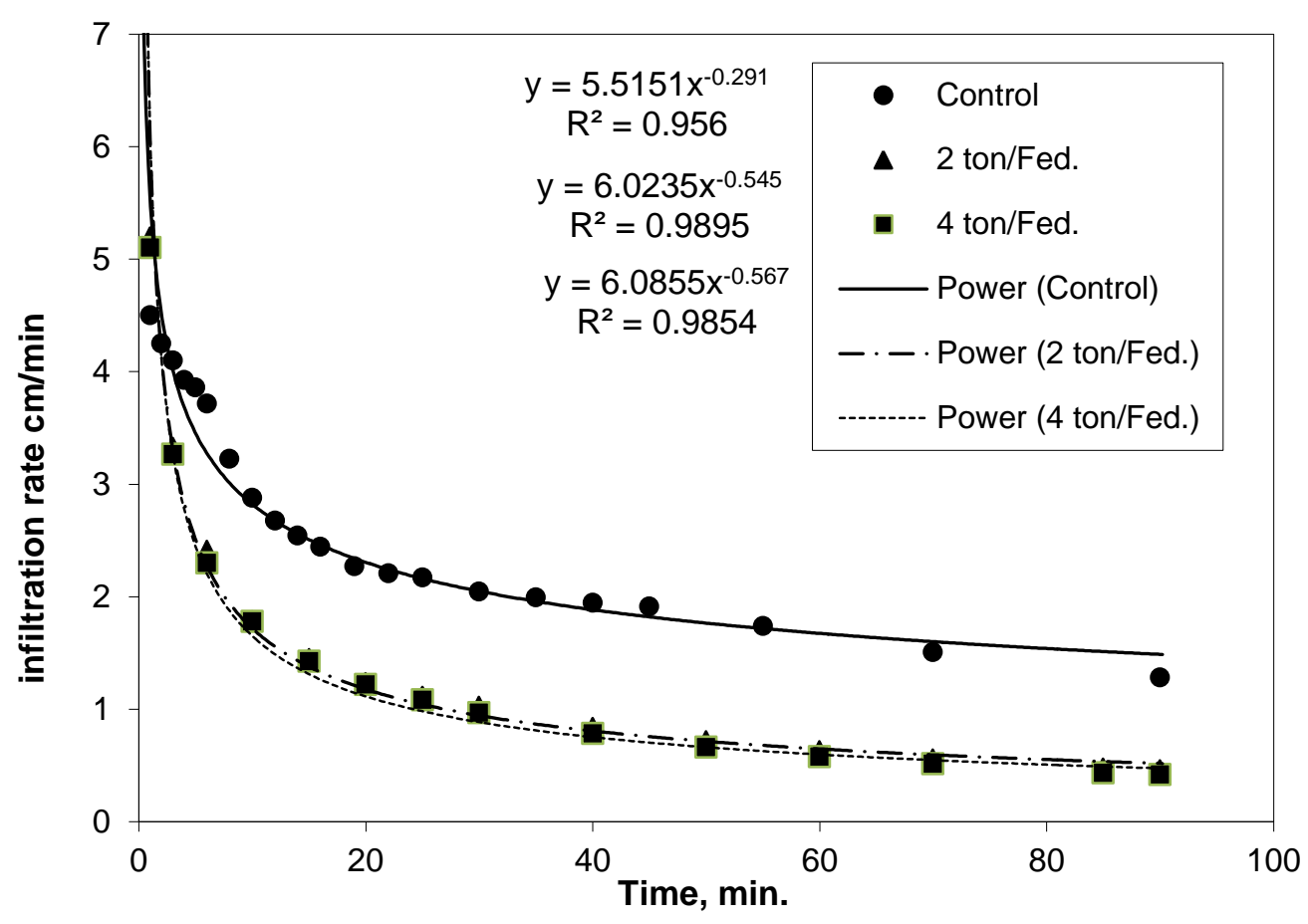

Fig 9: Effect of polyester geotextile application on soil infiltration rate.

Polyester is better than cotton in the price and durability and better than compost because it is environmentally safe and do not infect soil with insects, bacteria or fungus. Furthermore, it is easy to be packed, transported and applied to soil. Moreover, geotextiles should maintain water and keep the area around seeds and roots moist, which should reflect positively on plant. Alam et al. (2017) stated that, polyester could be treated, using moisture management chemicals, to produce micro-denier polyester fabric with high ability to absorb water. In this respect, Grubb et al. (2000) and $\mathrm{Li}$ et al. (2010) studied the durability of polyester geotextiles and found it long-lasting, which is good economically compared to cotton.

\section{Conclusion}

Wastes of cotton and polyester fabrics are superior compared to compost in many aspects such as: it is clean, easy to pack and transport. Moreover, it is free of dust, herb seeds and bad smell and not infected with nematode or insects or fungi. The three studied amendments (i.e. compost, cotton geotextile and polyester geotextile) were effective. The amendments application could be easily mechanically installed to large-scale (open fields), to any chosen depth, using proper plows, such as Turning Disc and Moldboard. The discussion clarifies that hydraulic conductivity, soil water retention and soil infiltration characteristics were successfully improved with geotextiles application. The study recommended that using polyester geotextile as an amendment of sandy soil, for its favorable effect on hydraulic conductivity and its effect on reducing the depletion rate of sandy soil available water. Further studies are needed to evaluate germination, plant growth and yield affected by different types, application rates and depths of geotextiles in open fields with different irrigation systems and to calculate lateral 
water movement using single ring comparing to double ring infiltration. Further studies are required to test the effectiveness of applying geotextiles in compacted and heavy textured soils to rapid soil water recession, reduce runoff and soil erosion. Moreover, there is a need to evaluate geotextiles as a soil conditioner to enhance the reclamation of saline and alkaline soils.

\section{REFERENCES}

Abu-Farsakh, M., Q. Chen and R. Sharma (2013). An experimental evaluation of the behavior of footings on geosynthetic-reinforced sand. Soils and Foundations (53)2: 335-348.

Alam, M.M., M.A. Chowdhury, E.J. Sabnam and M.S. Islam (2017). Improvement of moisture management of polyester fabric using moisture management chemical. Inter. J. Eng. Tech. Manag. App. Sci. 5(8):7078

ASTM D 1777 - 96 (2007). Standard test method for thickness of textile material. ASTM international, USA.

Basu, G., A.N. Roy, S.K. Bhattacharyya, S.K. Ghosh, G.B. asu, A.N. Roy, S.K. Bhattacharyya and S.K. Ghosh (2009). Construction of unpaved rural road using jute-synthetic blended woven geotextile - A case study. Geotextiles and Geomembranes. 27(6): 506-512.

Bathurst, R.J., G. Siemens and A.F. Ho (2009). Experimental investigation of infiltration ponding in onedimensional sand-geotextile columns. Geosynthetics International. 16(3): 158-172.

Bhattacharyya, R., M.A. Fullen, K. Davies and C.A. Booth (2009). Utilizing palmleaf geotextile mats to conserve loamy sand soil in the United Kingdom. Agriculture, Ecosystems \& Environment 130(1-2): 50-58.

Cole, D.R. (2015). Characterization and analysis of porosity and pore structures chemical sciences division, National Laboratory, Oak Ridge, Tennessee, USA. Mineralogical Soc. America. Reviews in Mineralogy \& Geochemistry. 80: 61-164.

Dhanapal, R., A.S. Tayade, A. Bhaskaran and P. Geetha (2018). Efficient water management in sugarcane with composted coir pith and sugarcane trash under tropical Indian conditions. Society for Sugar Research \& Promotion, Springer (published online: https://doi.org/10.1007/s12355018-0593-3).

Giménez-Morera, A., J.D. Ruiz Sinoga and A. Cerdà (2010). The impact of cotton geotextiles on soil and water losses from Mediterranean rainfed agricultural land. Land Degrad. Develop. 21: 210-217.

Grubb, D.G., W.E. Diesing, S.C.J. Cheng and R.M. Sabanas (2000). Comparison of geotextile durability to outdoor exposure conditions in the Peruvian Andes and the southeastern USA. Geosynthetics Intern. 7(1): 23-45.

Hsieh You-Lo (1995). Liquid transport in fabric structures. Textile Res. J. 65(5):299-307.

Horrocks, A.R. and S.C. Anand (2016). Handbook of technical textiles. $2^{\text {nd }}$ Ed. Wood head Publishing, Elsevier.

Iryo, T. and R.K. Rowe (2004). Numerical study of infiltration into a soilgeotextile column. Geosynthetics Intern., 11(5): 377-389.

Koemer, R.M. (2016). Geotextiles from design to applications. 1- Early background and history of geotextiles. (pages 3-15). Wood head Publishing, Elsevier.

Li L., M. Frey and K.J. Browning (2010). Biodegradability study on cotton and polyester fabrics. J. Eng. Fibers and Fabrics. 5 (4): 42-52.

Misnon, M.I., M.M. Islam, J.A. Epaarachchi and Kin-Tak Lau (2014). Potentiality of utilising natural textile 
materials for engineering composites applications. Materials and Design 59: 359-368.

Müller, W.W. and F. Saathoff (2015). Geosynthetics in geoenvironmental engineering. Sci. Tech. Adv. Materials. $16(3)$

Nnadi, E.O., S.J. Coupe, L.A. SañudoFontaneda and J. RodriguezHernandez (2014). An evaluation of enhanced geotextile layer in permeable pavement to improve stormwater infiltration and attenuation. Inter. J. Pavement Eng. 15(10): 925-932.

Omran, W.M., S.A. Hassan and M.A. Fadl (2013). Benefit from agricultural waste to improve the properties of desert Land and resist environmental pollution. Life Sci. J. 10(1): 3457-3465.
Pattnaik, T., B. Yasagar and B. Arisamal (2016). Application of geotextiles in pavement. Inter. J. Eng. Sci. Res. Tech. 5(4): 850-860.

Perrier E.R. and A.B. Salkini (1991). Supplemental irrigation in the near east and north Africa. ICARDA. Field measurement of infiltration. 10: 145153.

Ryan, J., G. Estefan and A. Rashid (2001). Soil and plant analysis laboratory Manual. $2^{\text {nd }}$ ed. ICARDA, Syria.

Yamanouchi, T. (1986). Historical review of geotextiles in Japan. Geotextiles and Geomembranes. 4(3-4): 165-178.

Wanas, Sh.A. and W.M. Omran (2006). Advantages of applying various compost types to different layers of sandy soil: 1- Hydro-physical properties. JASR. 2(12): 1298-1303. 
تقييم استخدام الجيوتكستايل في الأراضي الرملية: التأثثر على استنزاف المياه والتوصيل الهيدروليكي والرشتح

\author{
وائل محمد عمران
}

قسم علوم الأراضي - كلية الزراعة - جامعة المنوفية

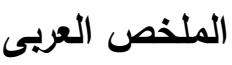

تستخدم كلمة جيوتكستايل للالالة على الأمشثة أو المنسوجات التي تستذدم في التربة للأغراض المختلفة. وتعتبر

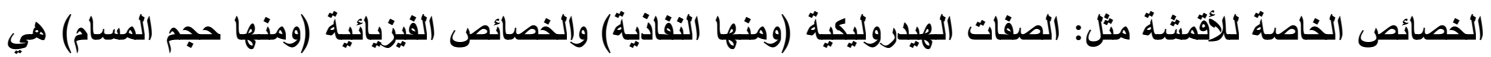
التي تحكم أداءها الوظيفي في التربة.

ويتميز الجيوتكستايل بالأفضلية عن الأسدة العضوية في العديد من الجوانب مثل: النظافة وسهولة التعبئة والنقل وخلوها من الأترية والروائح الكريهة ويذور الحشائش والنيماتودا فضلا عن عدم نقلها للعدوى سواء الحشرية أو الفئل الفطرية

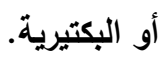
ويهاف هذا البحث إلى تقييم تأثير الجيوتكتيليل على التوصيل الهيلروليكي واستنزاف المياه الصالح للامتصاص

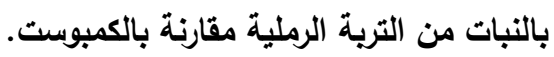
ولتحقيق هذف البحث ، أجريت تجربة معطلية باستخام اسطوانات بلاستيكية تملأ بأرض رملية والتي يضاف الئية اليها

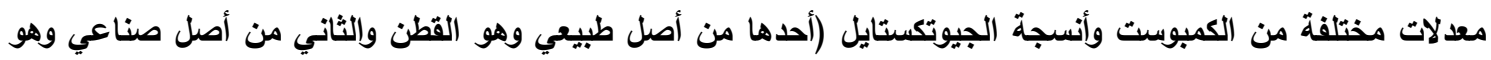

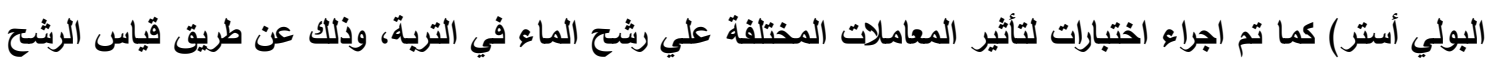

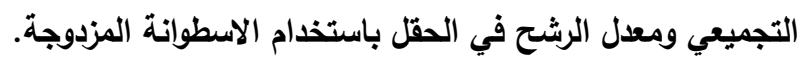

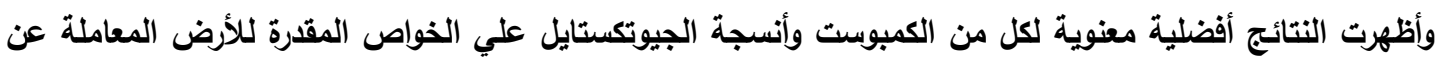

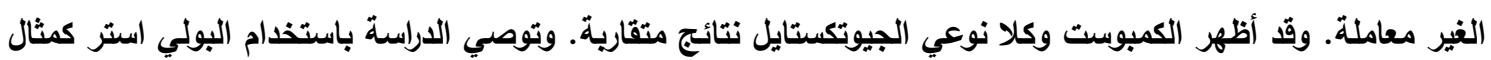

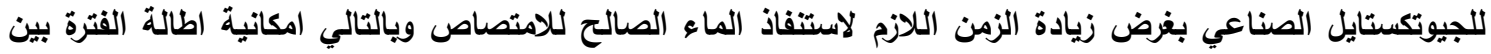

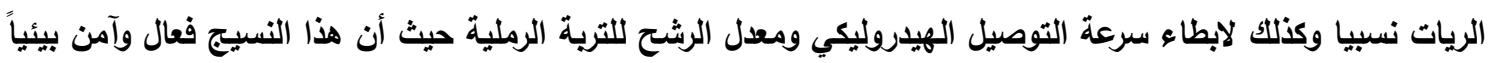

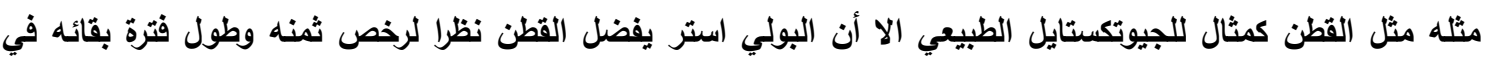

الكلمات الافتتاحية: جيوتكستايل - استنفاذ ماء التربة - التوصيل الهيروليكي - الرشح - الأرض الرملية. 
أ. أد/ محمد عصام شوقى كلية الزراعة - جامعة القاهرة

أ.د/ جمال عبد الناصر كلية الزراعة - جامعة الأسكندرية

Field studies of the effects of jute geotextiles on runoff and erosion in Shropshire, UK

D.J. Mitchell

1

*, A.P. Barton

1

, M.A. Fullen

1

, T. J. Hocking,

1

Wu Bo Zhi

2

and Zheng Yi

Field studies of the effects of jute geotextiles on runoff and erosion in Shropshire, UK

D.J. Mitchell

1

*, A.P. Barton

1

, M.A. Fullen

1

, T. J. Hocking,

1

Wu Bo Zhi

2

and Zheng Yi

Field studies of the effects of jute geotextiles on runoff and erosion in Shropshire, UK 
